\title{
COMMENTARY
}

\section{Comments by the Auditing Standards Committee of the Auditing Section of the American Accounting Association on the PCAOB Rulemaking Docket Matter 029: PCAOB Release No. 2011-007, Improving Transparency Through Disclosure of Engagement Partner and Certain Other Participants in Audits}

Participating Committee Members:

Keith L. Jones, Jagadison K. Aier, Duane M. Brandon, Tina D. Carpenter, Paul Caster, Ling Lei Lisic, and Mikhail B. Pevzner

SUMMARY: In October 2011, the Public Company Accounting Oversight Board (PCAOB or Board) issued a release to solicit public comment on amendments to its standards that would improve the transparency of pubic company audits. The objective of the release was to solicit public comments on a proposed standard that would (1) require registered public accounting firms to disclose the name of the engagement partner in the audit report, (2) amend the Board's Annual Report Form to require registered firms to disclose the name of the engagement partner for each audit report already required to be reported on the form, and (3) require disclosure in the audit report of other independent public accounting firms and other persons that took part in the audit. The PCAOB provided for a 91-day exposure period (from October 11, 2011, to January 9, 2012) for interested parties to examine the release and provide comments. The Auditing Standards Committee of the Auditing Section of the American Accounting Association provided the comments in the letter below to the PCAOB on PCAOB Rulemaking Docket Matter 029: PCAOB Release No. 2011-007, Improving Transparency Through Disclosure of Engagement Partner and Certain Other Participants in Audits.

Data Availability: Information about and access to the release is available at: http:// pcaobus.org/Rules/Rulemaking/Docket029/PCAOB_Release_ 2011-007.pdf 
RE: PCAOB RULEMAKING DOCKET MATTER 029: PCAOB RELEASE NO. 2011-007, IMPROVING TRANSPARENCY THROUGH DISCLOSURE OF ENGAGEMENT PARTNER AND CERTAIN OTHER PARTICIPANTS IN AUDITS

Dear Board Members:

The Auditing Standards Committee of the Auditing Section of the American Accounting Association is pleased to provide comments on the PCAOB Rulemaking Docket Matter No. 029: PCAOB Release No. 2011-007, Proposed Rule on Improving the Transparency of Disclosure of Engagement Partner and Certain Other Participants in Audits.

The views expressed in this letter are those of the members of the Auditing Standards Committee and do not reflect an official position of the American Accounting Association. In addition, the comments reflect the overall consensus view of the Committee, not necessarily the views of every individual member.

We hope that our attached comments and suggestions are helpful and will assist the Board. If the Board has any questions about our input, please feel free to contact our committee chair for any follow-up.

Respectfully submitted,

Auditing Standards Committee

Auditing Section-American Accounting Association

Contributors:

Chair-Keith L. Jones, George Mason University

Jagadison K. Aier, George Mason University

Duane M. Brandon, Auburn University

Tina D. Carpenter, The University of Georgia

Paul Caster, Fairfield University

Ling Lie Lisic, George Mason University

Mikhail B. Pevzner, George Mason University

\section{GENERAL COMMENTS}

The Committee commends the PCAOB ("the Board") for addressing the issue of including partner signatures on the audit report. The following section presents a number of specific comments or suggestions, organized along the lines of the questions posed by the Board in the proposed rule.

Here are comments to selected questions in the proposed rule:

1. Would disclosure of the engagement partner's name in the audit report enhance investor protection? If so, how? If not, why not?

Based on existing research, there is reason to believe that disclosure of the engagement partner's name in the audit report would enhance investor protection. Some countries (e.g., Australia, Taiwan, Sweden, China) already require disclosure of engagement partner names. Using this data, academic researchers conclude that engagement partner characteristics matter to audit quality. For example, Chi et al. (2011) find that an audit partner's pre-client and client-specific experience is associated with higher earnings quality and creditors' perceptions of higher audit quality. Knechel et al. (2011) show that partner compensation policies affect audit quality in Swedish clients. Hence, investors may find this information useful. Ceteris paribus, investors 
would prefer more experienced partners whose personal incentives are aligned with those of shareholders.

We note that, given the size of the audit market in the United States, the disclosure of the engagement partner's name may not have as dramatic an effect as shown in studies in smaller markets. However, requiring disclosure would provide market participants with potentially useful information as well as data for researchers to assess its usefulness.

2. Would disclosing the name of the engagement partner in the audit report increase the engagement partner's sense of accountability? If not, would requiring signature by the engagement partner increase the sense of accountability?

We believe that both disclosure of the partner's name and his/her signature would be useful. Disclosing the partner's name allows investors to track partner behavior more efficiently over time. Requiring a signature also should have a positive effect on audit quality since it should foster a partner's sense of personal accountability for the audit. Requiring audit partner signature on the audit report is analogous to the SOX 302 requirement that CEOs/CFOs sign 10-K reports. Prior research has established that $\mathrm{CEO}$ reputation is a strong disciplining mechanism when it comes to corporate malfeasance; specifically, CEO turnover is much more likely in the presence of accounting irregularities (Hennes et al. 2008) or restatements (Desai et al. 2006). Job prospects of executives following accounting restatements are much worse due to reputational effects. Similar arguments should apply to audit partners who do sub-par work.

3. Does the proposed approach reflect the appropriate balance between the engagement partner's role in the audit and the firm's responsibility for the audit? Are there other approaches that the Board should consider?

We believe that both the audit partner's name and his/her signature are useful in increasing the audit partner's sense of accountability to the audit. While disclosure of the engagement partner's name is informative, it does not clearly bind the engagement partner to the audit work or attest to the quality of the audit. Requiring the engagement partner to sign the audit report enhances accountability and ensures that the engagement partner certifies that the audit was performed in accordance with PCAOB standards and to the best of his/her abilities.

\section{Would the proposed amendments to the auditing standards create particular security risks that warrant treating auditors differently from others involved in the financial reporting process?}

Security risks arising out of increased transparency and individual liability can most likely be negated by some form of insurance for audit partners similar to directors and officers (D\&O) liability insurance. One possible problem would be the number of direct calls and correspondence an engagement partner may get from shareholders, investors, analysts, or other interested parties. It raises concerns about what the engagement partner may or may not disclose about a company's performance, plans, and financial health outside of what is required in the audit report.

\section{Would the proposed amendments to the auditing standards lead to an increase in private liability of the engagement partner? \\ We are not experts in this area. However, it seems likely that partners would be subject to frivolous personal lawsuits as a result of their personal association with problematic audits. In addition, the proposed amendments may lead to privacy and security issues for engagement partners. Thus, we do recommend that the Board give consideration to these potential negative consequences.}


12. If the Board adopts the proposed requirement that audit reports disclose the name of the engagement partner, should the Board also require firms to identify the engagement partner with respect to each engagement that the firms are otherwise required to disclose in Form 2?

Since Form 2 summarizes all information for a convenient review by investors, we think that it is useful to also require disclosure of engagement partner names in Form 2. Behavioral research in accounting suggests that easily accessible information is more effectively and efficiently used by consumers of accounting information.

13. If the Board does not adopt the proposed requirement that audit reports disclose the name of the engagement partner, should the Board nonetheless require firms to identify the engagement partner with respect to each engagement that the firms are otherwise required to disclose in Form 2?

We recommend disclosing audit partner names, whether it is in audit reports or Form 2, but preferably in both. In addition, if the Board does this, it will certainly facilitate research into individual engagement partner quality.

14. Disclosure in the audit report and on Form 2 would provide notice of a change in engagement partner only after the most recent period's audit is completed. Would more timely information about auditor changes be more useful? Should the Board require the firm to file a special report on Form 3 whenever there is a change in engagement partners?

Shareholders prefer more timely information. Bryant-Kutcher et al. (2011) find that SOX's requirement of accelerated $10-\mathrm{K}$ filing deadlines increases the value relevance of financial reporting. A similar argument can be applied here. Shareholders need to be notified of any material changes in the company. Audit partner turnover is important information. Studies have shown that the stock market reacts significantly to audit firm turnover. For example, Dunn et al. (1999) and Eichenseher et al. (1989) find that switching from Big N to non-Big N auditors raises a "red flag" to investors. Knechel et al. (2007) find that firms switching between Big 4 auditors experience significant positive abnormal returns when the successor auditor is an industry specialist and that they experience significant negative abnormal returns when the successor auditor is not a specialist. We expect that the market would react similarly to audit partner turnover if the audit partner's identity is publicly available. Consistent with our expectation, Fried and Schiff (1981) show that the market reacts negatively to CPA switches. Immediate reporting will be particularly useful if an engagement partner resigns or steps down from a particular audit because it would highlight whether the change in engagement partner was attributable to differences with company officials or disagreements within the audit firm.

20. Would disclosure of offshoring arrangements (as defined in the release) or any other types of arrangements to perform audit procedures provide useful information to investors and other users of the audit report? If yes, what information about such arrangements should be disclosed?

We believe that such disclosure may provide benefits. We recommend additional research on the quality of "offshored" audit work. The extent of work as measured by hours (proposed later in the release) would be appropriate.

21. Would disclosure in the audit report of other participants in the audit provide useful information to investors and other users of the audit report? Why or why not?

We believe that investors would like to know who participated in the audit besides the engagement partner. The individuals who perform the work largely determine the quality of the work. If investors know the names of the participants, they are better able to make informed 
judgments regarding the overall quality of the audit. It also is important to know the percentage of hours attributable to other participants so that investors can form judgments regarding the quality of the audit. The requirement is particularly relevant for multinational audits where the main auditor relies on other audit firms or their branch offices to conduct parts of the audit.

In addition, a requirement to disclose other audit participants would lead to additional research in this area that would inform investors and regulators about the quality of work provided by "other participants."

22. Are the proposed requirements sufficiently clear and appropriate with respect to identifying other participants in the audit? If not, how should the proposed requirements be revised?

We believe that the proposal is clear in stating the requirement.

23. Are the proposed requirements sufficiently clear as to when the name of a public accounting firm or a person would be required to be named in the audit report? Is it appropriate that the name of the firm or person that is disclosed is based on with whom the auditor has the contractual relationship?

We believe that the proposed requirements are sufficiently clear and that the example is very helpful in describing the requirement. We think that it is appropriate to disclose the name of the firm (person) based on the contractual relationship because it (he/she) is the entity that is legally liable for the work performed.

24. Would disclosure in the audit report of other participants in the audit have an impact on the ability of independent public accounting firms to compete in the marketplace? If so, how would the proposed requirement impact a firm's ability to compete in the marketplace?

Disclosing other participants in the audit would help the audit firms establish and maintain a reputation for audit quality if the firms consistently use other similarly competent firms to help complete the work. Greater disclosure of other participants in the audit improves investor confidence in the audit firm and also creates a mechanism to promote high-quality firms.

31. Should disclosure of the names of all other participants in the audit be required, or should the Board only require disclosing the names of those whose participation is 3 percent or greater? Would another threshold be more appropriate?

We do not think that disclosing all participants in the audit is necessary. In addition, investors do not want information overload. The focus should be on key participants. We recommend disclosure of names of those whose participation is more than 10 percent. A 10 percent threshold reflects a balance of supply of sufficient information while avoiding information overload.

32. Is the proposed manner in which other participants in the audit whose individual extent of participation is less than $\mathbf{3}$ percent of total hours would be aggregated appropriate?

Again, while we would recommend a 10 percent threshold, the manner proposed is appropriate.

33. Are the requirements to disclose the name and country of headquarters' office location of the referred-to firm sufficiently clear and appropriate?

We believe that the requirement to disclose the name and country of headquarters' office location of the referred-to firm is sufficiently clear and appropriate.

35. In situations in which the audit report discloses both the referred-to firm and other participants in the audit, would using different disclosure metrics (e.g., revenue for the referred-to firm and percentage of the total hours in the most recent period's audit for the 


\section{other firms and persons) create confusion? If so, what should the disclosure requirements be in such situations?}

We do not believe that the different disclosure metrics would cause any confusion.

\section{REFERENCES}

Bryant-Kutcher, L., E. Peng, and D. Weber. 2011. Regulating the Timing of Disclosure: Insights from the Acceleration of 10-K Filing Dates. Working paper, Colorado State University.

Chi, W., L. A. Myers, T. C. Omer, and H. Xie. 2011. The Effects of Audit Partner Pre-Client and Client-Specific Experience on Earnings Quality and on Perceptions of Audit Quality. Working paper, National Chengchi University.

Desai, H., C. Hogan, and M. Wilkins. 2006. The reputational penalty for aggressive accounting: Earnings restatements and management turnover. The Accounting Review 81 (1): 83-112.

Dunn, J., D. Hillier, and A. P. Marshall. 1999. The market reaction to auditor resignations. Accounting and Business Research 29 (2): 95-108.

Eichenseher, J., M. Hagigi, and D. Shields. 1989. Market reaction to auditor changes by OTC companies. Auditing: $A$ Journal of Practice \& Theory 9 (1): 29-40.

Fried, D., and A. Schiff. 1981. CPA switches and associated market reactions. The Accounting Review 56 (2): $326-$ 341.

Hennes, K. M., A. J. Leone, and B. P. Miller. 2008. The importance of distinguishing errors from irregularities in restatement research: The case of restatements and CEO/CFO turnover. The Accounting Review 83 (6): 14871519.

Knechel, R., L. Nielmi, and M. Zerni. 2011. Financial Incentives in Big 4 Accounting Partnerships and the Implications for Audit Quality. Working paper, University of Florida.

Knechel, W. R., V. Naiker, and G. Pacheco. 2007. Does auditor industry specialization matter? Evidence from market reaction to auditor switches. Auditing: A Journal of Practice \& Theory 26 (1): 19-45. 